\title{
Urgences
}

\section{les désirs...}

\section{Marie-Rose Comeau}

Numéro 13, mars 1986

\section{Éclats d'atelier}

URI : https://id.erudit.org/iderudit/025231ar

DOI : https://doi.org/10.7202/025231ar

Aller au sommaire du numéro

\section{Éditeur(s)}

Urgences

\section{ISSN}

0226-9554 (imprimé)

1927-3924 (numérique)

Découvrir la revue

\section{Citer ce document}

Comeau, M.-R. (1986). les désirs... Urgences, (13), 71-72.

https://doi.org/10.7202/025231ar

Ce document est protégé par la loi sur le droit d'auteur. L'utilisation des services d'Érudit (y compris la reproduction) est assujettie à sa politique d'utilisation que vous pouvez consulter en ligne.

https://apropos.erudit.org/fr/usagers/politique-dutilisation/ 


\section{Marie-Rose Comeau}

les désirs me tenaillent, me taraudent et je rêve d'un gâteau aux fraises et à la crème d'où émane une odeur ténue, crème à la vanille dégoulinant paresseusement jusqu'au plateau qui supporte le gâteau enrobé de cette crème de rêve laquelle est d'une couleur pâle et d'une texture douce comme un sein de jeune fille en janvier, des vallées envoûtantes, des vallons mystérieux, des rondeurs à faire frémir, il ne faut pas que j'y goûte, le désir ne résisterait pas quand, l'attente finie, je resterais triste, regrettant les formes, le goutte à goutte, l'inconnu de la pâte qui se cache sous ces formes à la Rubens, fragile, frémissante, onctueuse, solide mais flexible, ferme mais d'une douceur de soie, prête à couler en moi, sur moi, dans ma bouché, pour mettre en érection mes papilles amoureuses, mes papilles gustatives, il est vrai que I'on ne goûte vraiment que les lèvres tout à fait pleines, écrasées, écartelées, l'essence de cette pâte importe peu, le désir qui monte en moi, qui me serre la gorge, provoque une osmose, je suis la pâte, chair bonne à manger, gonflée de turgescences en forme de fraises, grosses, dodues, juteuses, suintantes, rouges ou violacées, je m'épuise à les lécher, je ne veux pas croquer, elles sont trop coquettes avec leur bonnet mince, pâle, qu'une main invisible repousse jusqu'à leur nuque nerveuse, mes désirs se précisent, j'ai faim d'un homme mature, avec un phallus long et nerveux, de ma main droite, je lui coule du sable tiède sur les cuisses, sur les aines, sur le ventre, mon sein de femme sûre effleure sa bouche d'un mamelon irrité, l'homme est sidéré, ses yeux sont rivés sur le triangle de mon pubis, sa bouche grimace de plaisir quand mes doigts s'égarent entre ses cuisses, tout ça m'excite étrangement, je me fais l'amour à moi-même, ses jambes nerveuses me serrent le bassin, il ne sait plus à quel saint se vouer, je sais qu'il est prêt à exploser comme un garçon, il ne s'occupe pas de moi, je suis une chose qui le fait jouir, cette attitude centuple mon désir, la sueur nous coule sur le ventre, son phallus oscille de la tête comme un métronome, je suis sereine, consciente du liquide qui mouille ma vulve, je ne veux pas de coït, une 
goutte de liquide perle, retarder l'orgasme, il faut que l'attente se prolonge, Vladimir et Estragon attendaient Godot, l'insaisissable qui ne viendra pas, moij'attends mon Godot, il ne viendra pas cet orgasme, le gâteau restera intact, la crème sur le gâteau, les fraises têtes nues, je me contente de sentir, lécher, toucher, regarder, le désir brillera à jamais de tous ses feux, il ne sera pas brûlé, non. Herma Phrodite est seule, brûlante de désir, hautaine et inaccessible, désirable, désirée mais gardant le désir non assouvi, c'est ce qui fait son mystère, elle n'a besoin de personne, elle comporte en elle-même 